\title{
A NEGAÇÃO DA OBRA: DERRIDA E LEITOR DE ARTAUD
}

\author{
Mayara Joice Dionizio* \\ mayaradioniso@hotmail.com
}

\begin{abstract}
RESUMO Em "A escritura e diferença", Derrida apresenta uma crítica à interpretação de Blanchot sobre Artaud, sob o título "A palavra soprada", na qual ressalta que a leitura blanchotiana foi tendenciosa. Seu incômodo se dá primeiramente pela comparação que Blanchot faz de Hölderlin e Artaud, por serem poetas que experimentaram a exigência poética e, por isso, tiveram suas obras interpretadas por um reducionismo da Psiquiatria. Para Derrida, esse duplo interpretativo, clínico e crítico, é decorrente de uma separação dualista há muito presente, uma diferença constitutiva da metafisica que gera todas as separações, inclusive a condição de comentário da clínica e da crítica. Assim, o que é exposto por Derrida é a deflagração de uma estrutura metafísica que suporta esses dualismos. O modo como Artaud percebeu esse limite de realização na escrita é o que Derrida tenta reconhecer como uma efração estrutural da diferença que há no nosso modo de se relacionar com a obra. Derrida refaz o caminho da obra de Artaud para mostrar como poderíamos superar essa ausência que acontece na relação do artista com a obra, do corpo e do espírito. E, por fim, demonstra a partir do próprio Artaud o reducionismo feito também por Blanchot.
\end{abstract}

Palavras-chave Artaud, comentário, obra, metafisica, escrita, diferença.

ABSTRACT In his book "Writing and difference", Derrida presents a critique of Blanchot's interpretation of Artaud, under the title "La parole souffé [The whispered word], in which he implies Blanchot's reading was biased. First, 
his discomfort occurs because of the comparison Blanchot makes of Hölderlin and Artaud, for both being poets that experimented the poetic demand and, because of that, had their works interpreted through a psychiatric reductionism. For Derrida, this clinical and critical double interpretive stems from a dualistic separation that has long been present, a constitutive difference of the metaphysics what creates all division, including the condition of commentary on clinic and critic. Hence, what is exposed by Derrida is the deflagration of a metaphysical structure that supports these dualisms. The way Artaud realized this limit of achievement in writing is what Derrida tries to recognize as a structural effraction of the difference that exists in our way of relating with the work. Derrida remakes the path of Artaud's work to show how we could overcome this absence that occurs in the relation between the artist and the work, the body and spirit. Finally, it shows - from Artaud himself - the reductionism made also by Blanchot.

Keywords Artaud, commentary, work, metaphysics, writing, difference.

\section{Unidade}

Derrida propõe uma restituição da unidade vida e obra, isso remonta a outra problemática: a da unidade entre loucura e obra. No início de "A palavra soprada", é deflagrada uma suposta ingenuidade que compromete toda leitura feita até aquele momento do caso Artaud. A possível redução dessa ingenuidade seria a abertura de um diálogo entre o discurso clínico e crítico. No entanto, nesse mesmo período em que tentaram aproximar ou distanciar ambos os discursos, surgiram comentários como os de M. Foucault, J. Laplanche e Blanchot, defensores de um unitarismo e de uma parcialidade criticadas por Derrida. Desse modo, Derrida se refere a publicações de textos que apresentam interrogações sobre a divisão entre loucura e obra, como a que se observa em "Le nom du père", artigo publicado em 1962 por Foucault (apud Derrida, 2011, p. 250) na revista Critique.

Estes dois discursos, apesar da identidade de um conteúdo sempre reversível de um para o outro e para cada um demonstrativo, são sem dúvida de uma profunda incompatibilidade. A decifração conjunta das estruturas poéticas e das estruturas psicológicas jamais reduzirá a sua distância. E contudo estão infinitamente próximos um do outro, como está próxima do possível a possibilidade que a fundamenta; é que a continuidade do sentido entre a obra e a loucura só é possível a partir do enigma do mesmo que deixa aparecer o absoluto da ruptura. 
Derrida defende que os dois discursos que aqui compõem o cenário de uma discussão não se confundem em conteúdo e emitem suas interpretações tendo como base o gênero comentário, e assim lança uma pergunta: "e o que é um comentário?" (Derrida, 2011, p. 250), a fim de responder a essa questão por meio da obra de Artaud. Nesse mesmo contexto, Blanchot contribuiu com o comentário $^{1}$ em que traça uma possível aproximação entre Hölderlin e Artaud, o qual Derrida utiliza como objeto de análise. O que deve ser avaliado após a análise de Derrida é se a aproximação entre Hölderlin e Artaud ainda pode ser tomada pelo rastro do discurso clínico ou do discurso crítico. De fato, são dois discursos que surgiram na França em franca oposição e que se valeram de casos como os de Artaud e de Hölderlin para amparar suas teorias. Percebe-se de imediato a posição de Blanchot nesse debate, ao lado da crítica literária e, portanto, do discurso crítico, ainda que não ignore completamente o discurso clínico. Se há um possível encontro entre esses dois poetas, para Blanchot, isso se dá no nível da experiência poética, da busca pela transgressão da linguagem, e não em uma estrutura psicológica comum.

Se de um lado temos o discurso clínico, que traça a impossibilidade de fato, ${ }^{2}$ determinante e de caráter irreversível, temos do outro a crítica, que, a fim de proteger a obra ou o pensamento de um artista, faz de casos como o de Artaud também um exemplo. Nesse sentido, a singularidade, tanto de Hölderlin quanto de Artaud, para Derrida, é negligenciada a fim de se provar um posicionamento, seja crítico ou clínico, e que os colocam como objeto fenomenológico de criação literária ou de obra como resultado de estados psicológicos.

Embora se oponham de maneira radical e pelas razões válidas que conhecemos, aqui, perante o problema da obra e da loucura, a redução psicológica e a redução eidética funcionam da mesma maneira, têm, contra vontade, o mesmo fim. O domínio que a psicopatologia, qualquer que seja o seu estilo, poderia obter do caso Artaud, supondo que atinja na sua leitura a séria profundidade de Blanchot, chegaria por fim à mesma neutralização "desse pobre M. Antonin Artaud” (Derrida, 2011, p. 251).

1 Há dois comentários escritos por Blanchot que servem como escopo para uma crítica derridiana: "Artaud", ensaio presente em "Le livre à venir", que é tido como comentário principal porque é dele que decorre a crítica central de Derrida a Blanchot, como é apresentada neste artigo; no entanto, há um outro comentário, "La cruelle raison poètique" que consta em "L'entretien infini”, que a aproximação entre Hölderlin e Artaud é feita mais uma vez.

2 Derrida sinaliza duas impossibilidades: de fato e de direito. A primeira é associada à patologia e à história; por isso, de fato. A segunda, de direito, se caracteriza pela impossibilidade que assume a obra poética de criar uma impossibilidade artística, a necessidade de tomar a impossibilidade como direito para transgressão, "de que modo uma impossibilidade de fato pôde dar-se para uma impossibilidade de direito?” (Derrida, 2011, p. 250). 
Em diversos escritos de Artaud, vemos sempre a rigorosa não aceitação da separação da unidade que, para Derrida, não foi respeitada por Blanchot, para quem a essencialidade é o que possibilita a negação do único. Ao afirmar uma essência do fazer poético, Blanchot teria neutralizado a singularidade de cada experiência em busca de um fundamento comum a toda e qualquer experiência com a escrita. Segundo Derrida, enquanto Artaud clama pela singularidade de sua experiência e, portanto, sua indissociabilidade com a vida, Blanchot tenta buscar um elemento comum a diferentes experiências quando diz que "seria tentador aproximar o que dissemos de Artaud do que nos dizem Hölderlin, Mallarmé" (Blanchot, 2013, p. 54).

Se o olhar que destinou à obra, principalmente às cartas, que delineavam o relato da falta já foi lançado na busca de um entendimento e delimitação do que é a criação poética, se foram esses os motivos, a aproximação já foi determinada muito antes de ser proferida e nela já consta, portanto, uma leitura comprometida do que disse Artaud. O mesmo podemos pensar de sua interpretação de Hölderlin, que é tido como um receptáculo da verdade da obra poética. Se nos voltarmos para o conjunto das críticas literárias escritas por Blanchot, encontraremos, em um primeiro momento, uma ontologia da poesia que mais tarde dá lugar a uma pré-ontologia, mas que em todas elas constam não mais a figura do escritor, e sim a busca incessante dessa essência, desse elemento que se insinua na experiência literária. Então, para que a arbitrariedade não pareça um postulado, todos os escritores são diluídos em suas obras e são tidos como receptáculos para Blanchot.

A suspeita de Derrida reside na escolha de Hölderlin e Artaud tanto pela crítica quanto pela clínica. No caso da clínica, essa aproximação se deve à suposição da esquizofrenia dos dois poetas, mas não na leitura de Blanchot, na qual, além de uma oportunidade de crítica ao reducionismo da clínica, reside também uma ontologia poética. Segundo Derrida, Blanchot utiliza a mesma ferramenta argumentativa que o reducionismo clínico: sobrepondo elemento artístico ao diagnóstico clínico e ignorando assim uma possível coerência nesse discurso.

Assim, Derrida integra ao diálogo a censura feita por Laplanche a Blanchot, que em "Hölderlin e a questão do pai", tentou entender algumas supostas arbitrariedades nas leituras que a crítica literária fez de Hölderlin, especialmente Blanchot: "os críticos literários não reconhecem na ruptura de 1801, que segundo Jaspers correspondia ao momento de aparecimento do processo psicótico" (Laplanche, 1991, p. 17). Se, de um lado, temos alguns estudiosos da Psiquiatria e da Psicologia fazendo um reducionismo da obra como mero sintoma, de outro há também uma redução do discurso clínico por parte dos críticos. No texto de Laplanche, há uma leitura um pouco distinta da de Derrida sobre a posição 
que Blanchot ocupa nesse cenário. Laplanche e Derrida enquadram Blanchot em uma leitura metafísica, "“anti-psicológica' e 'anti-científica"” (Laplanche, 1991. p. 18).

Para Laplanche, Blanchot é um idealista e unitarista que não reconhece a questão da esquizofrenia: o que a Psicologia chama de determinante ou de fato é, para Blanchot, tão somente a obra começando a surgir por meio do poeta. Em outras palavras: a loucura é na verdade uma exigência da poesia sobre o modo de vida, ou de negação da vida em prol da obra. A vida se torna secundária, ela é sacrificada em favor da obra. Tal é a primeira relação com a ausência com que o poeta se depara. Laplanche assinala que se o discurso crítico não reconhece no período de 1800-1801 o surgimento da psicose em Hölderlin é porque interpreta como a experiência poética de seus primeiros grandes hinos. De tal modo, para Blanchot, no ano de 1801 não houve o ápice da psicose, portanto, da obra como resultado da doença, ou como algo ocasionado pela doença, mas sim a exigência dos hinos agindo sobre Hölderlin.

Já para Derrida, configurava-se como essencialismo a base desse unitarismo, pois a essência que garante o unitarismo é também o que depõe contra o único. Ao buscar o fundamento da poesia, Blanchot acreditou haver uma fonte que originava a obra. Portanto, se todas as obras literárias vêm do mesmo elemento criador, sendo ele qual for, então fica evidente a universalidade da experiência poética. O discurso blanchotiano está calcado nessa ontologia poética, que só pode se manter às custas de uma não singularidade de quem escreve ou uma singularidade momentânea. Apesar de identificar diferenças entre poetas e poetas, essas singularidades não são o que possibilitam o surgimento poético, mas são antes a afirmação do caráter impessoal poético. O único, como nesse caso, desaparece na exemplaridade, desaparece pela essência, na palavra, o que se justifica, para Derrida, na ideia de dialética entre duas estruturas que pretendem sempre se sobrepor ou se combinar.

A desaparição da unicidade é mesmo apresentada como o sentido da verdade hölderliana: “[...] A palavra autêntica, a que é mediadora porque nela o mediador desaparece, põe fim à sua particularidade, regressa ao elemento que saiu" (p. 30). E o que deste modo permite dizer sempre "o poeta" em vez de Hölderlin, o que torna possível essa dissolução do único, é o fato de a unidade ou a unicidade do único - aqui a unidade da loucura e da obra - ser pensada como uma conjuntura, uma composição, uma "combinação": “Não se encontrou duas vezes semelhante combinação' (p. 20) (Derrida, 2011, p. 254).

Apesar de criticar a visão blanchotiana sobre Hölderlin, Laplanche não renega o unitarismo. Seu ponto é conseguir acentuar a dialética dessa conjunção e pontuar que o encontro entre loucura e obra garante a unidade hölderliana. $\mathrm{O}$ que para Derrida termina por coadunar com o exemplarismo ao qual ele criticava, 
pois, ao traçar a dualidade no único, ele não tenta mais entender o poeta por uma via de acesso (psicológica ou transcendental), mas sim justificar a particularidade em uma abertura para a verdade possibilitada pela esquizofrenia. A partir disso, a tentativa de Derrida é de mostrar que essas leituras sempre prosseguiram por dois caminhos: que seria necessário proteger a obra da conceituação que pudessem fazer dela ou reduzir a unidade a decompondo, colocando em partes para melhor entender e exemplificar. A crítica a esses comentários reside no seguinte ponto: para Derrida, não se trata de entender Hölderlin a partir de uma "estrutura esquizofrênica" ou uma "estrutura transcendental", mas sim de interpretar tendo como premissa um "acesso exemplar" do poeta por uma outra via, que não a comum, ou seja, pelo acesso da poesia "à essência da esquizofrenia" (Derrida, 2011, p. 255).

Por esse motivo, também Artaud, para Derrida, não é de forma alguma a introdução de uma obra na qual se assentam os princípios para a boa compreensão dessa dualidade, mas sim a apresentação de uma unidade que não aceitou se dissociar. Isso porque não se encontra nele uma via de acesso, como tardiamente tentaram desenhar em Hölderlin, mas, antes, já do juízo psicologista ou crítico, o sentido de uma arte sem obra que recusa a exemplificação, como acontecimento único e anterior à separação. Derrida reconhece assim a esterilidade das considerações da crítica e da clínica diante de Artaud. Esses comentários apontam, segundo Derrida, justamente para aquilo que Artaud quis destruir: a diferença entre vida e obra de arte.

Se nos é possível estabelecer nessa metafísica a responsabilidade pela existência da obra, ela também possibilita a existência do comentário. O que Derrida requer, nessa abordagem de Artaud, é transpor essa fissura contida nos comentários e que, até ali, utilizaram-se também de Hölderlin como uma ponte para a exegese e restauração. Então, se a metafísica dualista se estende a tudo, se o comentário é possível pela "dualidade da alma e do corpo sustentando, em segredo sem dúvida, a da palavra e da existência, do texto e do corpo, etc." (Derrida, 2011, p. 257), é porque a palavra que nessa estrutura se distancia do corpo se torna obra: é porque ela é soprada.

O sopro sustenta o cair longe da palavra. O rapto se dá, para Artaud, quando percebe que a palavra nessa estrutura não é mais comunicativa, sobrando apenas o que podemos compreender da falta que há na fala do outro, da impossibilidade de preencher por mesmo não conseguir se ausentar. O comentador é quem tenta preencher essa falta com um entendimento ajustado à sua visão de mundo. Daí o teatro da crueldade ter a função que não encontramos na poesia. No teatro já não há uma dissociação, que aqui delimitaremos neste primeiro momento por essa figura do usurpador, do público. O sopro é o furto porque oferece a palavra a um ouvinte que já não é mais apenas receptáculo, que na tentativa de 
apreensão e compreensão também soprará essa palavra. No mesmo sentido, os comentários feitos sobre Artaud, são calcados nessa origem furtiva. A essência do roubo é a origem da linguagem. Aprendemos a roubar primeiramente pelas palavras, e o discurso surge como oportunidade do roubo e resultado dele.

Mas o roubo da palavra não é um roubo entre outros, confunde-se com a própria possibilidade do roubo e define a sua estrutura fundamental. E se Artaud no-lo dá a pensar, já não é como exemplo de uma estrutura, pois se trata disso mesmo - o roubo - que constitui a estrutura de exemplo como tal (Derrida, 2011, p. 258).

Derrida estabelece assim uma ontologia estrutural da linguagem no roubo. Isso aponta para o sopro da inspiração que se configura na concepção de teatro sustentado pela literatura, ou seja, esse sopro acontece como que inspirado "por uma outra voz, lendo ela própria um texto mais velho que o poema do meu corpo, que o teatro do meu gesto" (Derrida, 2011, p. 257). Nesse sentido, a inspiração é como um ponto que garante a diferença entre o autor do texto e o intérprete; ela possibilita que se justifiquem as divisões de funções, colocandose como sopro em serviço da maquinaria do roubo. Mas se a inspiração pode ser definida como um fruto de uma ideia súbita ou, ainda, como uma força que exerce estímulo e influência, uma potência criadora, isso é porque sua relação com o sopro já está anunciada há muito. A ideia de afetar o outro por um sopro está associada à etimologia latina da palavra, que vem do verbo inspirare, que é a composição do prefixo "in" (em) com o verbo spirare (soprar), insuflar algo em alguém, "inspirada por uma outra voz" (Derrida, 2011, p. 258). Desse modo, a inspiração é a garantia do ponto dissimulador da origem da obra, principalmente no teatro clássico, em que se apresenta a estrutura de uma cisão muito maior: o escritor, dramaturgo que escreve, e o ator, que ausente ao texto deve lhe insuflar vida. Portanto, a proposta teatral artaudiana sempre teve como partida a restituição da afirmação teatral no corpo como uma abertura ao perigo do não partiturado por uma literatura, uma confluência emocional momentânea, estranha e sensível a todas as interferências.

Se o jogo proposto é o que traz a diferença, ${ }^{3}$ a consciência disposta na utilização de alguns termos também nos cobra dispêndio de atenção. Vê-se

3 Em uma conferência apresentada em janeiro de 1968 com o título "La différance", Derrida assinala uma alteridade na palavra com a troca do "e" por um "a transgressor". Em francês, a palavra "differénce" que se torna "différance" tem a intenção de diferenciar a palavra em si. Nas traduções feitas em Portugal e no Brasil, a palavra tem outra grafia: diferância (Portugal) e diferência (Brasil), para denotar a alteridade. Uma escrita interior à escrita, o mais direto seria traduzir para o português como "diferança", mesmo que sonoramente menor, já assinala o diferir da palavra mais próxima da troca feita por Derrida, como consta na tradução de "Margens da filosofia" (Derrida, 1991, pp. 33-34). 
que o conceito de exemplaridade segue sempre uma dubiedade estruturada nessa diferença que deve ser sublinhada para que prossigamos com os rastros derridianos. Ao criticar a ausência do único sobreposto pela desconstrução calcada em certa noção de exemplo, Derrida assinala a "diferança" em sua interpretação do termo.

Só aparentemente a exemplaridade contradiz a unicidade. A equivocidade que se alberga na noção de exemplo é bem conhecida; é o recurso da cumplicidade entre o discurso clínico e o discurso crítico, entre aquele que reduz o sentido ou o valor e aquele que gostaria de restaurá-los. É o que permite deste modo a Foucault concluir: “[...] Hölderlin ocupa um lugar único e exemplar” (Derrida, 2011, p. 256).

As unidades que apresentam escritos que optam entre loucura e obra, corpo e espírito, exemplo e essência só firmam e aprofundam a diferença nessa cisão. Então a diferança [différance] vem diferir das diferenças [différence] que se assentam nessas fissuras, nesses hiatos. A diferança restitui a falha causada pela diferença. $\mathrm{O}$ exemplo - ao contrário dos discursos partidários que o utilizam e acabam por separar mais ainda certas estruturas - assume outro sentido, o da diferença da unidade. É nessa diferença que consiste a restauração do único como abertura para o perigo; é destruindo a metafísica dualista, a inspiração poética, a arte clássica, que se despertaria para a crueldade.

Assim, Derrida assinala que o impoder, esse termo confessionário que Artaud fundamenta o processo de escrita para J. Rivière, longe de ser ausência de poesia, é "um deslize calculado" (Derrida, 2011, p. 256), por ser a inspiração em sua forma súbita, na qual oferece e retém algo ao mesmo tempo. A inspiração é o sopro que preenche e furta no segundo seguinte e que, antes que falemos por meio dela, já se ausentou, se contraiu e esvaneceu. É nesse vácuo entre um sopro e outro que se configura o impoder. E se há uma positivação da inspiração como sopro, seria o mesmo impoder que à primeira vista é impossibilitador. No entanto, é fecundo em sua espontaneidade pela irresponsabilidade da palavra já em sua origem, que pelo sopro estimula o acesso daquilo que subtrai, mas que inevitavelmente cria um ingresso.

Esse tocante essencial ao poder totalizante da linguagem é o que dela vem nos colocar a par: nossa falta consciente com a perda que nos constitui metafisicamente. Por isso, Derrida acusa o deslize orquestrado de Artaud que, sabendo do tratado mundano sobre a coerência, ao qual Rivière também servia, aceita a parcialidade de tratar o impoder apenas como insuficiência do que submeter sua escrita ao jugo da metafísica dualista que rege a literatura. Sua persistência em tratar o impoder era ocasionada pela presença da ausência da palavra, que julgava ser verticalizada nele. 
Portanto, a insistência de Artaud não é na eloquência da fala, na linguagem dita comum, mas sim na escrita da poesia em que o furto se assenta com força. A palavra "furtivo" está associada à fugacidade, mas a sucede, a extrapola, pois existe uma rapidez do furto agindo sobre o nada que há entre o significante e as palavras, subtraindo-as de si para que, quando esse sujeito as encontre, elas já sejam falta. A invisibilidade do furto está garantida na repetição da palavra, que só por sê-la, já é furto. Então, se podemos afirmar uma subtração que desapropria a linguagem, isso acontece porque não há palavra que não exista no furto: para que seja palavra, tem de ser partilhada em uma linguagem, ou seja, repetida, e toda repetição depende originariamente do sopro furtivo. Essa subtração é constituinte na palavra, pois ela não sabe sua origem ou seu fim; ela trabalha como intermediária e caminhante, sendo ausência. Assim, o sujeito que fala é secundário, não apreende o que fala, pois o ladrão já o despojou dela muito antes que dissesse algo.

Derrida mostra assim o "campo organizado da palavra" (Derrida, 2011, p. 261), que, antes de ser justificado na Linguística ou na Psicologia, está relacionado à cultura e à História que constituem esse sujeito em uma alfabetização de leitura e escrita. Se o roubo está entre a palavra e a língua, então ambas são assaltadas, além desse sujeito secundário. Mas então resta a figura do leitor, aquele que lê e que retira sua palavra e escrita de leituras, que longe de se aproximar mais de si, ou de uma apreensão, lhe é tirada a ênfase de falar primeiramente algo próprio. Isso se dá porque a palavra é aberta. E, sendo assim, ela se adapta ao entendimento de quem lê e não ao de quem escreve. Por sua vez, quem lê também será constituído por sua interpretação da palavra, e assim irá escrevê-la até que seja soprada a outro por meio da leitura. Resta-nos reconhecer que, se há alguma autonomia, está no leitor, no significante passivo que momentaneamente toca a palavra pela sua necessidade em suprir sua carência de entendimento dela. Logo depois, o leitor deixa a palavra ao aberto, ao devir da história e da cultura que está sempre para acontecer e, por isso, estará aberta aos vários sentidos que assumirá na língua.

Artaud nunca se pôs a esmiuçar essa estrutura como nos fez Derrida. Sua intenção sempre foi a explosão dessa estrutura, e o que aponta para outra concepção de inspiração, a diferança na inspiração. Se, como vimos, o sopro também insufla - e não só contrai -, nesse movimento encontra-se o sopro da vida. Isso era para Artaud a inspiração boa que preenche por um instante, seu projeto propunha que com a restituição feita pela crueldade a má inspiração não tivesse lugar de alojamento. 


\section{Metafísica da vida e metafísica da carne}

Para Artaud, a vida é a boa inspiração, sua forma primitiva, centro livre das formas. Mas, como Derrida aponta, essa metafísica da vida não deve estar ligada a certa concepção biológica e pulsional da criação literária, que se fundamenta nas formas, fatos e exterioridades. Se a categoria de furtivo até agora aparece ligada à escrita, depois da afirmação que é o teatro da crueldade, a escritura deve ser encarnada. Para tal, Artaud buscou diminuir a fissura entre força vital e forma, restaurando-as em uma coisa só: a vida. Seu resgate primitivista era pela ausência de forma e não pela obra.

Assim, quando pronunciarmos a palavra vida, é preciso ver que não se trata da vida reconhecida pelo exterior dos fatos, mas sim dessa espécie de centro frágil e instável no qual as formas não se tocam. E se existe ainda algo de infernal e de verdadeiramente maldito nos tempos de hoje, é determo-nos artisticamente em formas, em vez de sermos como supliciados em vias de serem queimados e que fazem sinais nas suas fogueiras (Le Théatre et la culture, v, p.18. O grifo é nosso) (Artaud apud Derrida, 2011, p. 263).

O teatro da crueldade tem como função diminuir essa diferença [différence] causada pela desapropriação do furtivo, que longe de subtrair somente a escrita e a fala, coíbe o próprio eu. Aqui podemos perceber o fio que liga o impoder à fase teatral de Artaud. Porque se essa ausência é percebida primeiramente na escrita, desencadeada na fala, no eu e na carne, a proposta de um teatro restaurador aparece como o resultado da falta primeira, a poética. Por isso a concepção de um teatro que, assim como sua escrita, não se estabeleça em subserviência a uma literatura regida pelo dualismo metafísico e também não compactue com a dicotomia do teatro clássico. Para isso, Artaud apresenta uma metafísica da carne, responsável por devolver a integridade entre corpo e espírito, palavra e pensamento, ser e vida, uma vez que o espírito pertence à matéria. $\mathrm{O}$ que orientaria essa metafísica da carne é a angústia do furto, do pensamento dissociado da palavra, da vida longe do espírito.

A carne está ligada à existência, e uma existência sem a separação é a vida da carne, a vida sem a diferença. É nela que existem as primeiras faltas desapropriadoras orquestradas pelo primeiro ladrão: Deus. A cisão sempre acontece com a abertura de uma lacuna, um orifício, o espaço que primeiro foi aberto, ou seja, uma diferença que já nasce conosco; trata-se, segundo Artaud, dos orifícios pelos quais nascemos, defecamos e temos gozo. Com isso, Artaud referia-se à carne como instrumento de restauro da obra, da existência, da cultura, já que é nela que temos nosso primeiro roubo.

É por esse lugar que é vazio e que é preenchido, pelo qual saímos e que também possuímos, que se demonstra que desde nossa concepção já somos 
roubados, se o lugar do roubo é um entre-lugar, já nascemos despojados e com a diferença. $\mathrm{O}$ roubo praticado pelo outro já existe desde o nascimento. Desse modo, somos roubados no nascimento, o que nos leva à concepção da morte como furto já deste nascer. E assim a morte também não é menos furtiva. Primeiramente, porque nascemos para morrer, isso já categoriza um roubo, o da vida em outra medida, diferente do roubo que caracterizamos até então. Em outro aspecto, a morte acontece como uma encenação: quem morre não detém a própria morte, ela é uma representação que o outro captará. Quando pensamos na morte como representação para o outro, o instante de acontecimento dela é representativo e, sem que nos demos conta, em toda nossa existência, em pequenos roubos, somos preparados para o ato representativo, para a morte, o furto final. "Deus é, portanto, o nome próprio daquilo que nos priva da nossa própria natureza, do nosso próprio nascimento e que, em seguida, furtivamente, sempre falou antes de nós. É a diferença que se insinua como a minha morte entre mim e eu" (Derrida, 2011, p. 125).

Essa duplicidade também levanta novamente o problema da cisão, da divisão em detrimento da unidade. Mas a leitura que Artaud expõe, segundo Derrida, é que o Demiurgo, sendo responsável pelo mal e pelo furto, alocou-se em seu corpo no momento de seu nascimento e lhe retirou um pedaço; assim, o destinou a sempre estar em falta, sempre em busca desse corpo. Por meio desse pedaço, conseguiu se passar por ele, assaltando-o sempre, e o matando em cada vez que agia sobre ele. Então a desapropriação é inata, Deus nos constituiu privados de nós e dentro de uma estrutura que é toda fissurada para que sustente todos esses roubos.

Se Artaud traça uma genealogia de Deus, é porque, mais do que descobrir a origem da sua subtração, quer descobrir a origem da obra de arte, que só é possível porque é o resultado dessa subtração. Seu argumento escatológico é a exemplificação da obra que Deus criou em nós para mais uma vez nos roubar. $\mathrm{O}$ excremento é produzido em nós, porém já não faz mais parte de nós e é expurgado. A eliminação do excremento também é um roubo; por isso, a única saída para evitá-lo seria guardar a obra para si mesmo, tentando evitar, desse modo, que o roubo aconteça e que o Ladrão não transforme em escritura o que lhe é próprio. A obra como excremento dissociado do criador se torna sem vida, e é justamente por isso que Artaud decide se desvencilhar da ideia de obra poética, pois a obra sem ele desmoronaria, morreria: "toda escrita é uma porcaria" (Artaud, 1991, p. 64). Não retirar a obra da vida, mas sim retê-la em si, significa que a obra sem o corpo, sem a força originária que a concebeu, não se sustenta, é morta. 
Eis por que a obra - poética ou não - jamais me colocará de pé. Nunca será nela que me erigirei. A salvação, o estatuto, o estar-de-pé, só serão possíveis numa arte sem obra. Sendo a obra sempre obra de morto, a arte sem obra, a dança ou o teatro da crueldade, será a arte na própria vida (Derrida, 2011, p. 128).

Dessa maneira, a noção de escritura, de poesia, só tem força porque, diante da diferença, é a única fonte de alguma expressão. Na angústia causada pela ausência, nesse espaço que nos descola do que nos é próprio, o máximo que se alcança de expressão é um conjunto material de signos, ou seja, a obra. Por isso, para Artaud, a obra escatológica nunca o restituirá desse nada simbolizado pela falta. Propõe então que a solução que faria impossível o rapto é reter a obra, não defecar; pois não haveria objeto do furto, apenas a confluência de tudo no eu. Isso enganaria o ladrão, que sem enxergar o que se deve furtar, o que é obra, ficaria sem objeto.

Assim, se a arte se constitui em um resultado que não apreende sua origem, é necessário que a arte permaneça na vida, e a única possibilidade disso está na ausência da diferença. Uma arte sem obra seria uma arte na vida, sem lugar para fissuras, o enfim “estar-de-pé” (Derrida, 2011, p. 269). Ressoa em Artaud a tradição de poetas ditos loucos; aqui, Derrida põe em evidência como essa ereção que encontra âmbito na palavra poética ou na dança aparece também em Hölderlin e em Nietzsche. Ainda que Derrida se atente para essa semelhança, com a cautela de não condescender ao erro que nesse texto se preocupa em denunciar (a comparação), identifica na tradição a mesma questão presente em Artaud: o "estar-de-pé” (Derrida, 2011, p. 270). Mas com uma ressalva: em Nietzsche e Hölderlin, a ereção ${ }^{4}$ encontra morada na obra, na poesia, na dança, e é essa expatriação, essa representação metafórica, que Artaud pretendeu aniquilar.

Ainda assim, Derrida diz que Nietzsche denuncia a origem da gramática como uma ilusão; ainda assim, busca libertar a dança e a música do texto. É possível traçar uma analogia entre alguns aspectos dos quais, segundo Derrida, levariam a uma conclusão de que se pode posicionar em qualquer um dos lados. No entanto, apesar de buscar a mesma restituição que Artaud também tentou pelo teatro, quando Nietzsche afirma a sua ereção na dança - "Só posso acreditar num Deus que saiba dançar" (Nietzsche apud Derrida, 2011, p. 274) - ela ainda se separa de uma totalidade. Porque, para Artaud, o teatro, além de

4 A expressão "ereção" aqui não tem sentido falocêntrico, mas sim de excitação poética/metafórica. Em que, antes do gozo, há a excitação, a força que é despendida na obra, no caso de Hölderlin e Nietzsche, na metáfora e que, para Artaud, deveria ser contida, guardada: "em todo caso a ereção não deve exilar-se na obra, delegar-se ao poema, expatriar-se na soberania da palavra ou da escritura, no estar-de-pé no pé da letra ou na ponta da pena" (Derrida, 2011, p. 271) e; "é a metáfora que Artaud quer destruir. Quer acabar com o estar-de-pé como ereção metafórica na obra escrita” (Derrida, 2011, p. 271). 
dever conter todas as expressões artísticas, também restituiria a divisão entre as artes, de modo que a dança não existisse longe do teatro, e vice-versa.

Ou trazemos todas as artes de volta a uma atitude e uma necessidade centrais, encontrando uma analogia entre o gesto feito na pintura ou no teatro e um gesto feito pela lava no desastre de um vulcão, ou devemos parar de pintar, de vociferar, de escrever e de fazer seja lá o que for (Artaud, 2006, pp. 87-90).

Nesse sentido, destruir a metáfora é também destruir Deus, pois o que alimenta a criação da obra poética é a superstição que há na ideia de que se pode encontrar o grande ladrão pela poesia. Assim, para Artaud, a salvação depende da destruição dessas entidades. Artaud aponta para a relação entre estético e divino, que é onde a natureza aparece. Buscando essa salvação pela morte de Deus e pelo resgate do divino, o paganismo é a afirmação do teatro da crueldade. $\mathrm{O}$ teatro que aceita a cesura entre corpo e texto, o teatro onde o único que detém qualquer "boa inspiração" é Deus, detentor da primeira palavra, é o teatro que aceita o órgão por definição e que se submete ao texto. $O$ teatro restituidor seria aquele que rejeita o imperialismo da letra e que se caracterizaria pelo indizível. Voltamos então ao hiato que mostra que o espaço do teatro para Artaud é o da ilegibilidade. O teatro deve atuar no ilegível e buscá-lo como evocador de ilegibilidade, que se entende por força e signo juntos quando antecedem o texto: "Na ilegibilidade teatral, na noite que precede o livro, o signo ainda não está separado da força. Ainda não é completamente um signo, no sentido em que o entendemos, mas já não é uma coisa, aquilo que só pensamos na sua oposição ao signo" (Derrida, 2011, p. 139).

Nesse movimento anterior, a força juntamente com o signo não está couraçada, revestida com a palavra. Mas, no modo pelo qual a linguagem usual articula esses dois termos, é quando ocorre a separação, garantindo a existência de ambos, força e signo, independentemente. Derrida coloca isso como uma característica própria do ideal europeu de linguagem: a separação entre força e signo é quando o signo ganha sentido no texto, como texto. Quando tentamos elevar a força acima do texto, essa força, ou espírito, ganha a classificação de metafórico. Dentro do teatro, tal separação é responsável por fazer do ator um mero intérprete.

Esta derivação da força no signo divide o ato teatral, deporta o ator para longe da responsabilidade do sentido, faz dele um intérprete que deixa que lhe insuflem a vida e lhe soprem as palavras, recebendo o seu papel como uma ordem, submetendo-se como um animal ao prazer da docilidade (Derrida, 2011, p. 281). 
Isso faz do espectador um consumidor, e do palco um não palco, pois já não é mais cruel, mas sim entretenimento. Nessa submissão, ele perde a si mesmo, aceita o sopro das palavras, por segurança, tornando-se o teatro do medo, pois já não é o espaço do perigo. A instauração do perigo no teatro é a renúncia ao teatro textual e ditatorial, que sobrevive pelo modelo de palavra, escritura, que é a palavra como representação de um pensamento fechado e acabado e de uma escritura que representa tanto foneticamente como alfabeticamente - uma representação que é levada para a escrita, para a fala, e que se sustém em um roubo constante. O teatro órgão, em que cada membro, assim como no organismo, exerce uma função: autor, diretor, ator, público.

Antes de desarticular os órgãos do teatro, é necessário começar pelo corpo que, restituído de si, restituirá todo o resto. Aqui está a famosa ideia de Artaud sobre o corpo sem órgãos, que aparece pela primeira vez em sua peça radiofônica "Para acabar com o julgamento de Deus". A ideia de restituir o corpo roubado por Deus se apresenta já no título ambíguo da peça, em que o demiurgo aparece tanto quanto juiz quanto como réu. Nesse texto, é apresentado, em quatro momentos, a desarticulação do corpo compartimentado pelas várias faltas dicotômicas. Tal desarticulação se dá primeiramente pelo ritual pagão, no qual o corpo é exorcizado na crucificação; seguidamente, a relação entre o roubo e as fezes, sendo Deus o responsável pelo roubo; no terceiro e quarto, a insuficiência da linguagem e um manifesto por um corpo não articulado em órgãos.

- O homem é doente porque é mal construído

Temos que nos decidir a desnudá-lo para lhe extrair essa fera que mortalmente o corrói deus,

e juntamente com deus

os seus órgãos.

Me coloquem numa camisa de força se isso lhes der prazer, mas não há nada mais inútil do que um órgão.

Quando conseguirmos um corpo sem órgãos teremos libertado o homem de todos seus automatismos e restituído a sua verdadeira liberdade.

Voltaremos então a ensiná-lo a dançar às avessas (Artaud, 1999, p. 68).

Um corpo segmentado em órgãos, com funcionamentos distintos, é o corpo articulado pela linguagem, calcado na separação da carne como ambiente para que aconteça a diferença. A estrutura do corpo articulado garante uma autonomia do órgão sobre o corpo, na qual um membro canaliza uma função em si, roubando do eu a experiência do todo. Mais um motivo pelo qual o corpo para Artaud, antes da restituição, é um corpo sujo, em que a ereção à qual já fizemos menção é sempre vivenciada de maneira segmentada, abandonada do corpo, mas ainda assim o sendo. O sexo é experimentado por um membro que 
expurga fluido, que também é obra. Se a divisão é vivenciada no corpo, sua reconstituição deve ser o fechamento desse corpo.

O teatro da crueldade surge como veículo de reconstrução desse corpo. Por isso, não é um gênero artístico a mais, mas a totalidade na qual unicamente pode se resgatar os órgãos, a palavra existindo no corpo como força e antes de ser palavra, a tatuagem sangrenta (Derrida, 2011, p. 277). O encarnar a letra em um primeiro momento seria suprimir a palavra, deixar que o corpo se restabelecesse pelo teatro em um emudecer, para que depois a voz, também desarticulada, sem ser guiada pelo texto, encontre seu lugar nesse teatro. Então, essa ruptura aconteceria para modificar a função e o lugar do texto, até que a voz fale pela carne e que se expresse não mais em definições, mas em vida.

Vemos então que Artaud não buscou romper com a palavra para aniquilá-la, mas sim a destruir, no sentido soberano usual que ela tem lugar, para ressignificar a si mesma longe do roubo. Nessa ressignificação, a palavra é a primeira entidade a ser atacada e redefinida, pois nela se desencadeiam todas as outras. Quando diz que há que se libertar o teatro da literatura, é porque o teatro deve subtrair o texto como seu instrumento principal, submeter a língua à ilegibilidade do teatro. Se o teatro da crueldade é o espaço dessa afirmação, é porque nele um gesto não se repete e, portanto, não cria códigos para uma nova linguagem ou o estatuto de uma obra.

Derrida ainda soma à noção de "acabar com as obras-primas", na qual Artaud percorre o caminho de fracasso que o teatro ocidental teve por se vincular à supremacia da obra, das formas e da literatura. Assim, não podemos falar em uma crítica ao teatro feito até aquele momento, mas sim de uma destruição dele: qualquer renovação desse teatro nesse sentido conservaria em si um diferir estrutural e fundamental, uma outra forma de literatura. Abandonarse ao furtivo, aceitar essa condição, é convir com o espetáculo que elenca o teatro como aparição para espectadores, é aceitar que a palavra seja soprada. Se Artaud refaz o teatro, é porque quer restituir a relação com o devir. Isso só pode ser feito sem demarcações estabelecidas dentro de possibilidades finitas, na medida em que estas são lógicas. Imprimir uma nova escritura teatral consiste então em descolonizar o teatro. Para isso, Artaud recorreu ao ideograma e aos hieróglifos como possibilidades de instituir a palavra sem definição, de tornar o signo físico.

Não é à custa da escritura mas entre duas escrituras que a diferança furtiva tinha podido insinuar-se, marginalizando a minha vida e fazendo da sua origem, da minha carne, o exergo e o jacente cansado do meu discurso. Era preciso, através da escritura feita carne, através do hieróglifo teatral, destruir o duplo, apagar a escritura apó-crifa que, roubando-me o ser como vida, me mantinha à distância da força escondida. Agora o discurso pode voltar a atingir o seu nascimento numa perfeita e permanente presença a si (Derrida, 2011, p. 285). 
Configura-se um duplo: a escritura e a escritura teatral. Se o projeto de Artaud foi em direção à destruição de uma concepção de pensamento, de sujeito, de metafísica, isso no fim de seu projeto retoma algum lugar. A questão inevitável que surge em torno da criação de uma nova linguagem que se pretende renovadora, reconciliadora, é a mesma inquisidora pergunta sobre a linguagem do sopro: não seria uma mudança de domínio, no qual se alojaria a insuficiência representativa e, por sua vez, faltante e furtiva? Derrida afirma que não. A ideia desse novo domínio é justamente não exigir lógica comunicativa, mas sim uma linguagem universal da crueldade que não está preocupada em representar e que, na verdade, quer apenas ter domínio sobre o sopro, para que ele não consiga agir como roubo. Isso denuncia a impossibilidade de domínio do sujeito sobre o mundo, em qualquer linguagem que assuma; daí um refazer dessa estrutura. Tanto o é que Artaud não propõe uma escrita fonética, só não produzindo palavra que conseguimos também fechar a origem da diferença e restituir o que foi roubado. Em seu último movimento restaurador, a escritura teatral destrói o duplo ao trazer a força velada, fazendo do devir da língua uma presença.Ao propor a não diferença, que é a ausência de obra, e com isso uma não história, Artaud está propondo, sim, uma outra obra, metafísica, língua, história, porém sem ajuizar como se fossem. Isso não se deve à ingenuidade, mas sim a outra noção do que ele mesmo entendia como sua produção, no sentido de não enxergar o que havia feito como obra, já não o pertencia mais e, por isso mesmo, eram restos de si. Assim, o campo que possibilitou esse projeto foi esse olhar, alienado ou não, de Artaud, foi o que talvez possa ser chamado de loucura - mas não no sentido arbitrário e reducionista, clínico ou crítico, e sim nesse espaço de abertura para se pensar outra metafísica, para além das possibilidades que ela mesma fecha. Isso que tentam definir como loucura, no campo da significação da alienação ou inalienação, ou mesmo como obra ou ausência dela, para Derrida, esses discursos continuarão a se confrontar infinitamente enquanto estiverem presos a essa metafísica que Artaud insistentemente denuncia.

A duplicidade que esse jogo apresenta vai em direção a esse limite; ao mesmo tempo em que a destruição se apresenta, ela também restitui. Derrida se vale de Heidegger nesse aspecto: tal duplo que identifica em Artaud é o mesmo presente no conceito de aletheia. ${ }^{5} \mathrm{Um}$ duplo em que a palavra revela e esconde

5 Em uma análise etimológica de aletheia temos a partícula privativa 'a' e a palavra 'lethes' que num sentido literal significa esquecimento, mas aqui entendido como o que foi ocultado, velado; portanto, aletheia se refere ao não velamento, como consta na obra "Compreensão e finitude". Nessa obra, encontra-se uma análise do uso dessa palavra pelos gregos, por diversos autores e obras literárias gregas, como a "Ilíada", na qual se conclui que a aletheia é apontada como "uma palavra com a qual os gregos pensam o que lhes é mais caro: a presença, o não-velamento. Enquanto presença, não-velamento, a palavra aletheia resume o pensamento 
essa diferença do furtivo em que se destrói uma tradição para se acordar outra, dessa vez uma que já seja calcada essencialmente na presença a si, a unidade, a identidade a si, o próprio etc. (Derrida, 2011, p. 287). Presença que busca deter o desvelamento como um âmbito de verdade presente. Essa nova metafísica escolhe, ao contrário da metafísica ocidental, a consciência e a afirmação da diferença. Uma outra metafísica na qual a crueldade governe a vida: se não podemos escapar ao furto (esse ato cruel), que tenhamos o seu domínio, que façamos a escolha consciente de ceder a ele e onde deixar que ele aja, uma presença que contenha uma lucidez sobre a ausência. Nesse sentido, quando a lei da crueldade é sempre apresentada por Artaud com a terrível constatação de que se pode entender por vida, rigor, necessidade é a afirmação do inelutável diante do inominável.

Artaud, ao denunciar esse limite da diferença, mais do que fazer apenas uma crítica à metafísica e acompanhar os seus passos de reconstrução de uma outra metafísica, demonstra que em todas essas estruturas encontramos uma cumplicidade que ele constata fatal. O jogo da diferença é unificado, pois ao mesmo tempo em que se abre a fissura, une-se o que está em seus extremos. E se o ponto de partida de "A palavra soprada" foi a restituição da unidade perante Artaud e Hölderlin reduzidos a meros exemplos, a constatação a que se chega agora, no fim do texto, é que essa cumplicidade - que Derrida coloca inicialmente como a única possibilidade de redução da ingenuidade das leituras sobre esses casos - só acontece porque ambos os discursos (clínico e crítico) são decorrentes dessa estrutura que eles próprios almejam reduzir. E se o caminho contra a ingenuidade da diferença na metafísica é justamente deflagrar, desconstruir a estrutura do roubo e assumir essa diferença, a abertura de um diálogo, como sugeriu Derrida, seria o caminho para que os discursos, não mais ingênuos, conseguissem alguma presença sobre a arte e seus dispositivos.

Mas retornemos à pergunta inicial que prenunciava uma posição que Artaud nos daria e que, segundo Derrida, refazendo o mesmo caminho, nos colocaria com alguma lucidez sobre "o que é um comentário?" (Derrida, 2011, p. 250). A primeira resposta se configura na denúncia: é a palavra, é a obra, é o roubo do roubo. Se a estrutura da linguagem configura o roubo, garante lugar para que ele aconteça e para que o ladrão proceda; o comentário é a alienação da alienação, pois, se quando eu falo já há ausência, quando outro comenta sobre

grego e contém em si o destino da filosofia ocidental" (Stein, 2001, pp. 72-73). Heidegger trata a verdade como aletheia, buscando nesse termo seu significado "originário", de forma que a verdade (aletheia) ocorre sempre no movimento do desencobrimento e encobrimento, no sentido de que não há um esgotamento da compreensão, pois há sempre a possibilidade de abertura de novos âmbitos. Aí se dá a oposição ao movimento de pensar a verdade como certeza e erro. 
aquilo que eu disse, o sopro acontece e se torna escritura, diferença, falta. $\mathrm{O}$ crítico e o clínico se apropriam exatamente da impossibilidade, confiam na palavra, em saberes constituídos sobre essas faltas, a da letra, a da Psicologia; e, em um embate, presumem que um possa se estabelecer sobre o outro. O que se fixa nesse embate é afirmação da ausência, que é inalienável.

Em outra perspectiva, em que se assenta esse horizonte de conclusão, Artaud rompe com o texto para reintroduzi-lo, querendo-se sem obra, mas ciente de ser autor de uma. Artaud compreende a si mesmo como circunscrito pela palavra, pelos limites que a linguagem lhe impôs, mas ainda assim buscando uma materialidade dessa palavra. É por essa mesma via que dá vistas a uma reformulação dela mesma - a linguagem, que também proferiu.

Gostaria de fazer um livro que perturbasse os homens, que fosse como uma porta aberta e os conduzisse aonde nunca teriam consentido ir, uma porta simplesmente conectada com a realidade. E isto é tão pouco um prefácio a um livro, quanto por exemplo, os poemas que o balizam ou a enumeração de todas as raivas do meu mal-estar. Isto não é senão um pedaço de gelo mal digerido (Artaud, 1991, p. 14).

Escrever um livro para acabar com o livro, escrevê-lo para abrir outro estado em que ele habitasse a vida, mas ainda assim escrevê-lo. Desse modo, para recusar a obra, ainda a afirma. Nessa posição em que coloca a pergunta, o problema, coloca também o limite desse problema e volta ao seu centro. Derrida refaz esse caminho, não para se provar certo, mas para mostrar que a contradição apresentada por Artaud testa os limites da própria linguagem e, simultaneamente, a desprotege desses limites. Derrida faz o mesmo quando escreve um comentário para criticar o gênero comentário. Se ao produzir uma obra escrita, ainda que seja para destruí-la e reconstruí-la no mesmo movimento, Artaud autoriza o roubo, o exemplo, do mesmo modo, Derrida tece um comentário para afirmar que não se deve comentar a partir de estruturas argumentativas parciais que não têm como pressuposto a unidade.

\section{Referências}

ARTAUD, A. "O pesa-nervos”. Tradução de J. Afonso. Lisboa: Hiena, 1991. "O teatro e seu duplo". Tradução de T. Coelho. São Paulo: Companhia das Letras, 2006.

. "Para acabar de vez com o juízo e Deus". Tradução de T. Hara e G. Giannattasio.

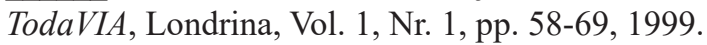

BLANCHOT, M. "Conversa infinita, - A ausência de Livro". Vol. 3. Tradução de J. Moura Jr. São Paulo: Escuta, 2010. 
. “O livro por vir”. Tradução de L. Perrone-Moisés. São Paulo: Martins Fontes, 2013.

DERRIDA, J. "Escritura e diferença". Tradução de M. B. M. N. da Silva. São Paulo: Perspectiva, 2011.

. "Margens da Filosofia". Tradução de J. T. Costa e A. M. Magalhães. Porto: RÉS-Editora, 1991.

LAPLANCHE, J. "Hölderlin e a questão do pai". Tradução de C. Marques. Rio de Janeiro: Jorge Zahar, 1991.

STEIN, E. "Compreensão e finitude: estrutura e movimento da interrogação heideggeriana”. Ijuí: Ed. Unijuí, 2001. 